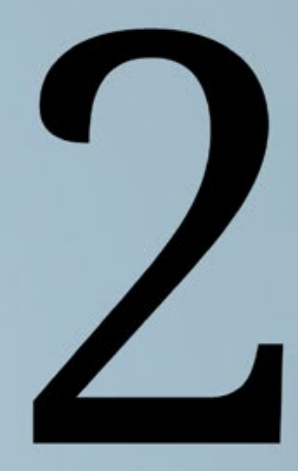


7月

8月

9月

10月

11月

\section{WHOSE SHARED DESTINY?}

\section{Richard Rigby and Brendan Taylor}
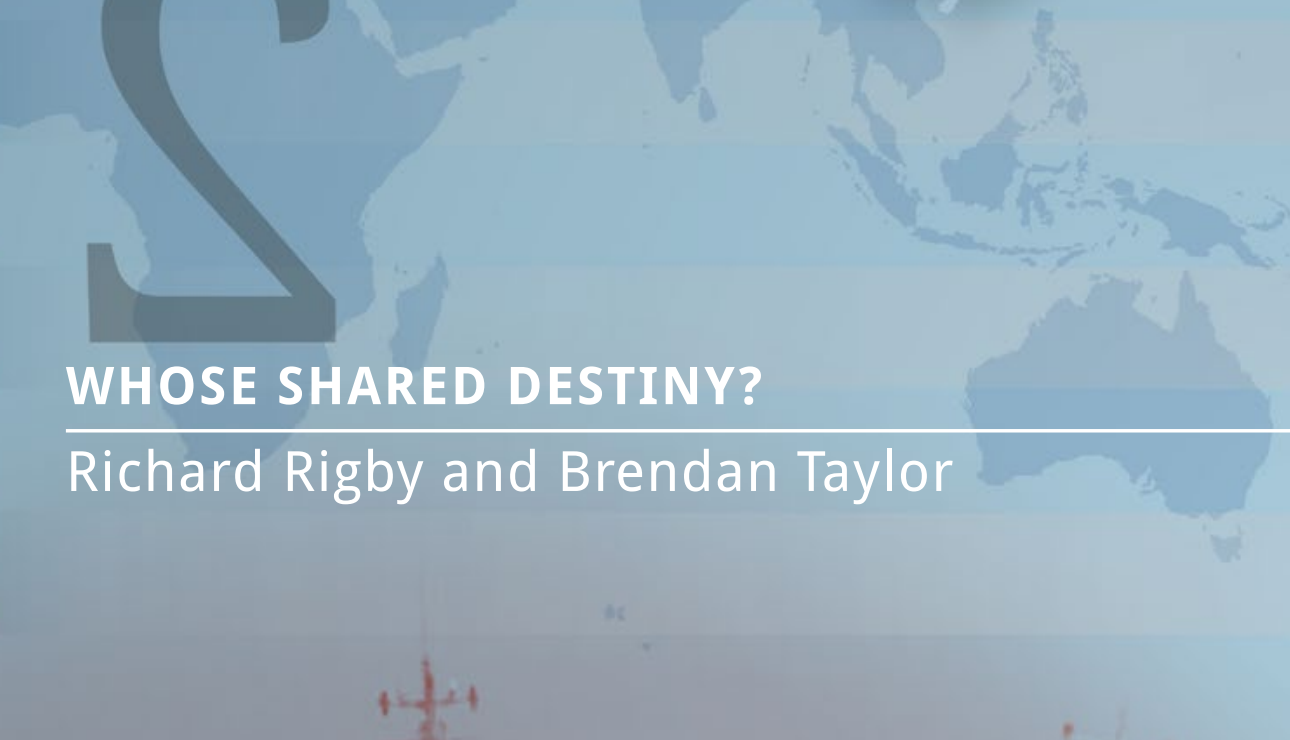

月

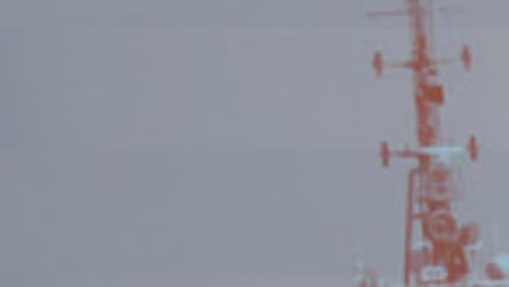




\section{THE 'COMMUNITY OF SHARED DESTINY'}

is not a completely new concept in Chinese foreign policy - the Communist Party first used the term in 2007 in relation to crossStrait relations. But it is one that has gained greater prominence over the past year. A key development during this period was Xi Jinping's October 2013 keynote speech at the 'Workshop on Diplomatic Work with Neighbouring Countries' 周边国家外交工作座谈会， during which he elaborated on the 'shared destiny' theme (sometimes translated into English as 'common destiny'): it was then that the term officially entered the Chinese foreign policy lexicon. 


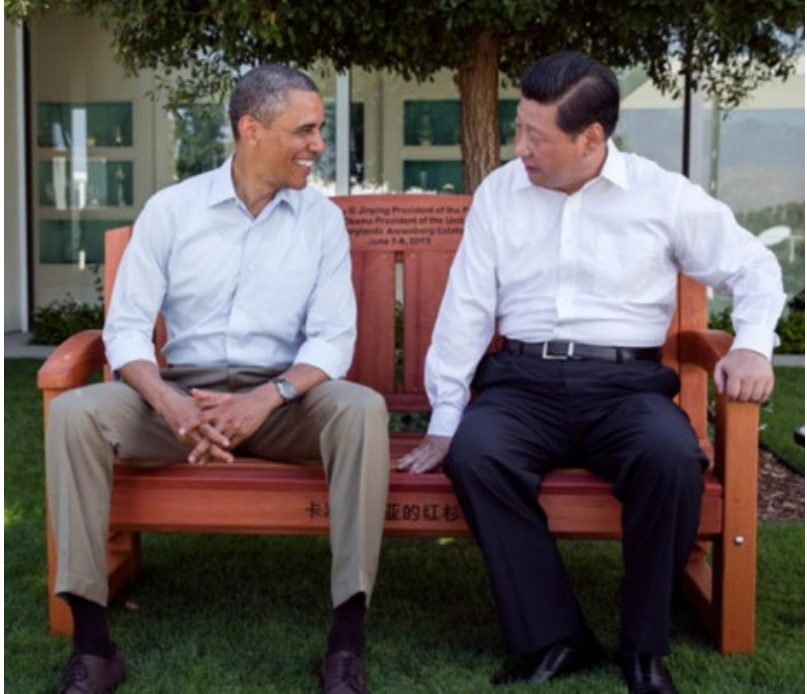

In June 2013, presidents Obama and Xi met for a two-day informal summit at the Annenberg Retreat at Sunnylands in California

Source: The White House

China is hardly alone in embracing foreign policy concepts that lack precision. Think of then US deputy secretary of state Robert Zoellick's call on China in 2005 to become a 'responsible stakeholder' and the call of then president $\mathrm{Hu}$ Jintao's contemporaneous formulation for a 'harmonious world', for example, or Kevin Rudd's 2008 vision of an 'Asia-Pacific Community' and 'harmonious world'. At its heart, the concept of a 'community of shared destiny' is essentially about ensuring peace and stability in China's external strategic environment through the development of good relations with neighbouring countries. Ironically, it is difficult to recall a period, in recent history at least, where there has been such a substantial gap between Beijing's public rhetoric and what it has been doing in practice, with the result that it has alienated, alarmed and infuriated many of its neighbours.

For some commentators, the 'community of shared destiny' represents a direct response to the US 'pivot' or strategy of 're-balancing'. Yet, as recently as June 2013, hopes were high that even China and the US might have been able to work towards a 'common destiny' when presidents Xi and Barack Obama held their so-called 'Sunnylands Sum-

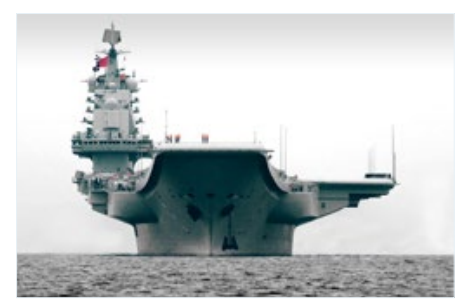

China's first aircraft carrier Liaoning went into commission on 25 September 2012. Rumours are rife that China is in the process of building a second aircraft carrier Source: reddit.com 
mit' in California. Some observers even went so far as to liken the meeting to the Mao-Nixon diplomacy of the 1970s in terms of its geopolitical significance. Ultimately, however, the outcomes of the summit were modest and relations between Beijing and Washington took on an increasingly competitive edge over the following twelve months. In December 2013, for instance, a standoff occurred in the waters of the South China Sea between an American Aegis cruiser, the USS Cowpens, and vessels escorting the Chinese aircraft carrier Liaoning. Chinese official media responses to this standoff asserted that 'Washington has to understand that Beijing has the right to grow its national defence capacity in accordance with its own legitimate demands to protect national interests'.

\section{New Models?}

Relations between Beijing and Washington became even tenser in 2014. In May, the US Justice Department took the unprecedented step of indicting five officers of the PLA from the so-called 'Unit 61398' in Shanghai, on charges of hacking into the networks of American companies dealing with aerospace, telecommunications, information technology,

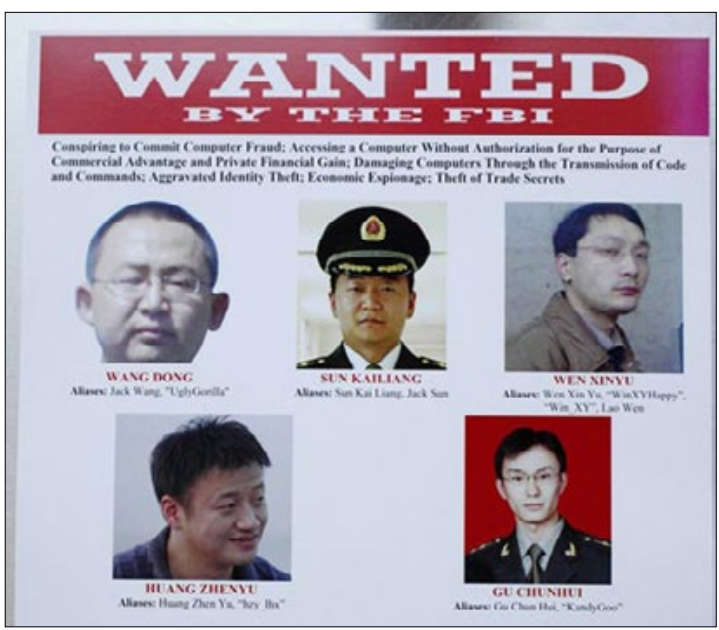

PLA 'Unit 61398' has allegedly hacked into the networks of more than 140 Western firms in pursuit of corporate secrets to support the Chinese government's political and economic aims Source: wantchinatimes.com satellite and other sensitive areas, also including Westinghouse Electric and US Steel Corp. The charges were largely symbolic given that the US does not have an extradition treaty with China - and in any case, China denies the army unit even exists. 


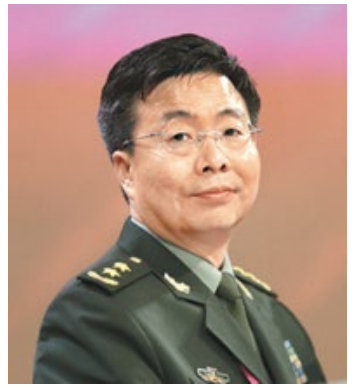

Wang Guanzhong

Source: hk.crntt.com:

Nevertheless, Beijing responded within hours of the indictment, denouncing the charges and calling in the US Ambassador to China, Max Baucus. One month later, the Shangri-La Dialogue an annual Asian security summit that is a useful barometer for reading the state of relations between Beijing and Washington - displayed deepening tensions. There, PLA Deputy Chief Wang Guanzhong 王冠中 delivered 'unscripted' remarks describing an earlier speech by US

Defense Secretary Chuck Hagel to the gathering as 'full of hegemony and threats'. Taken together, the rhetoric associated with another of Xi Jinping's central foreign policy concepts, or the 'New Model of Great Power Relations’新型大国关系, seems far from the reality of Sino-US relations during the previous twelve months.

A policy paper published under the auspices of the Korean-based Asan Institute for Policy Studies in March 2014 advocates applying the concept of the New Model to the Sino-Japanese relationship. However, over the past twelve months, tensions between the two historical great powers of East Asia have deepened and may even descend into conflict. In November 2013, China controversially declared a new Air Defence Identification Zone (ADIZ) 防空识别区 over the East China Sea and covering the disputed Diaoyu/Senkaku Islands. By February 2014, senior US military officials were accusing the PLA of preparing to fight a 'short, sharp war' against Japan designed to seize the disputed islands.

\section{Sino-Japanese Understanding}

Relations worsened in April 2014 when the Shanghai Maritime Court seized a Japanese cargo ship, Baosteel Emotion, in relation to an unpaid compensation claim dating back to the mid-1930s, when Japan leased two 


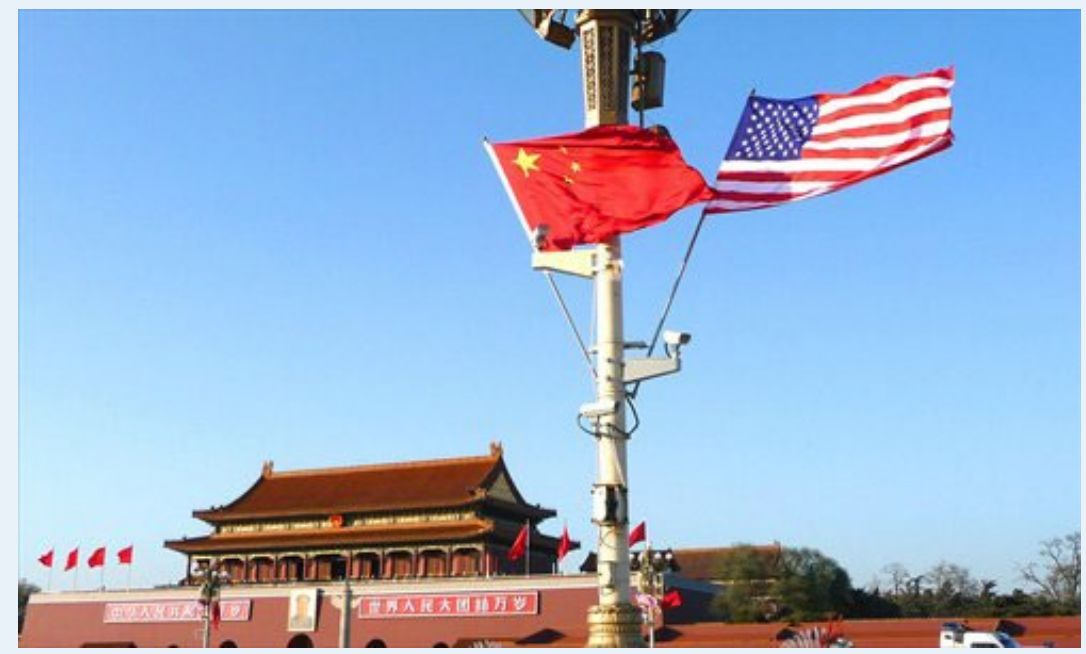

Tensions between Beijing and Washington escalated during the course of 2014 Source: tieba.baidu.com

\section{Silent Contest, by Jeremy Goldkorn}

Silent Contest 较量无声 is a low-budget gung-ho film produced by the General Logistics Department of the PLA and the National Defence University in mid-2013. It surfaced on the Internet in October 2013 only to be deleted soon after. Set to a portentous musical score, the film decries the collapse of the Soviet Union and accuses America of undermining the rise of China through military exchanges, consular activities, non-governmental organisations (NGO) and the propagation of Western values as well as Christianity. Among others it attacks the Ford Foundation, the Fulbright Scholarship program, the Carter Center, law professor and judicial reform activist He Weifang 贺卫方, eighty-four-year-old liberal economist Mao Yushi 茅于赋, electronic music and luxury brands as all harmful to the rule of the Communist Party and China's future. The central thesis of the film is that the collapse of the Soviet Union was not caused by the end of the Cold War but rather the other way round, in other words, infiltration, ideological softening and sympathy for Western ideas destroyed the Soviet Union. Although the production date is unknown, the two-part ninety-three minute film is assumed to have been made sometime after Xi Jinping's inauguration as state leader in March 2013.

The central thesis of the film harks back to the 1950s Cold War policies of John Foster Dulles and his brother Allen Dulles, who promoted peaceful evolution as well as covert activities to undermine countries in the socialist camp. 
Chinese ships and later lost them at sea. Baosteel Emotion's Japanese owner, Mitsui OSK Lines Ltd, swiftly resolved the conflict by paying the US $\$ 29$ million required to secure the release of the ship. A potentially far more deadly encounter occurred in May 2014 when Chinese SU-27 fighters reportedly flew as close as thirty metres from a Japanese surveillance plane operating near the Diaoyu/Senkaku Islands, a tactic the Japanese alleged was repeated again in mid-June.

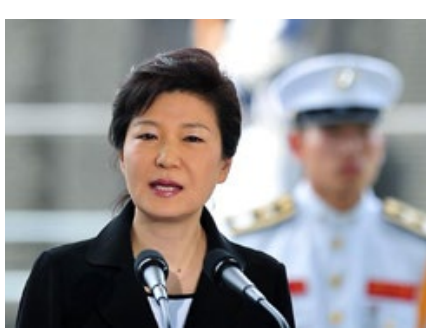

Park Guen-hye was sworn in as South Korea's first female president in 2013. She is the daughter of former South Korean President Park Chung-hee

Source: 3news.co.nz

\section{Peninsula Matters}

Over the last year Beijing has also managed to alienate two of its other key Northeast Asian neighbours, South and North Korea. In the case of the South, this was somewhat puzzling given that Beijing and Seoul seemed to be drawing closer in their mutual antipathy and suspicions toward Japan. The fact that the recently elected Park Guen-hye is the first South Korean president to speak Standard Chinese fluently only reinforced this growing intimacy. Yet China's ADIZ declaration upset Seoul: it covered not just the Diaoyu/ Senkaku Islands but also another set of disputed islets which the Koreans called Ieodo and the Chinese Suyan Rock. Seoul responded by expanding its own ADIZ and summoning the Chinese Defence attaché to lodge a protest. This issue reignited in May 2014 when Chinese and Russian forces staged a major joint military exercise approximately fifty kilometres from Ieodo/Suyan Rock. Seoul was further disenchanted with Beijing in May when it discovered more than 1,000 Chinese fishing vessels operating illegally in South Korean waters - a development that some commentators interpreted as China taking advantage of President Park's decision, following the Sewol ferry sinking disaster, to dismantle the South Korean Coast Guard. 
President Xi's July 2014 visit to South Korea led to a downplaying of these tensions and also to commentary suggesting that China was intent upon driving a wedge between the United States and one of its key Northeast Asian allies. This possibility was apparently not lost on senior American officials. Testifying before Congress in June, for instance, Assistant Secretary for East Asia and the Pacific Daniel Russel described Xi's visit as 'an extraordinary milestone'. The persistence of the existential North Korean threat to the South suggests that the prospects for an imminent strategic shift on Seoul's part are remote at this juncture. Indeed, polling conducted by the Asan Institute suggests that, while perceptions of China are warming, the US remains South Korea's most popular country and most important ally. If anything, the real historic significance of the Xi trip lay in the fact that he was the first Chinese leader to visit the South having not first visited the North.

The continued downturn in China's relations with its longstanding North Korean ally continued to surprise. A significant factor was North Korean leader Kim Jong-un's execution of Jang Sung-taek his uncle and the reclusive regime's point man on China policy. One of Jang's crimes was reportedly his closeness with China. Beijing appeared to have been completely blindsided by this development. Then, in March 2014, reports emerged that a North Korean missile test, of which Pyongyang

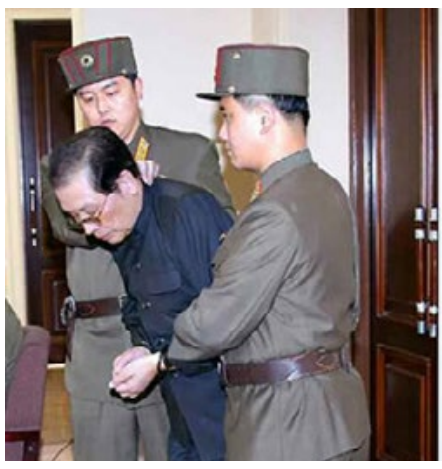

Sino-North Korean relations deteriorate: In December 2013, North Korean leader Kim Jong-un ordered the execution of Jang Sungtaek - his uncle and key policy advisor on China policy

Source: Unknown had failed to warn Beijing in advance, missed a commercial Chinese jetliner carrying 220 passengers by a number of minutes. In May 2014, the Japanese press reported the existence of leaked Chinese contingency plans preparing for the collapse of North Korean regime. Although Beijing vociferously denied these reports, Sino-North Korean relations grew even more strained. 
MH370, by Linda Jaivin

On 8 March 2014, the Malaysian Airlines Flight MH370 from Kuala Lumpur to Beijing lost contact with air traffic control less than an hour after its departure. The plane was carrying twelve Malaysian crew members and 227 passengers from fourteen nations - 152 of them from China. A search team organised by the Malaysian, Chinese and Australian governments, aided by Japan, the US, South Korea and Vietnam, searched from the coast of Vietnam to the Andaman Sea and the Bay of Bengal, without discovering any debris.

Relatives and friends of the missing passengers in China grew increasingly distressed and angry with the Malaysian government's handling of the affair, including its perceived lack of transparency and delays in passing on information, and staged protests. Chinese state media also voiced criticism of Malaysia, and Chinese social media flared with antiMalaysian sentiment.

One plausible theory held that the plane was flying on autopilot, but ran out of fuel and crashed somewhere near the Australian coast - which still doesn't explain why it was on autopilot or turned away from its course in the first place. Evidence in a report by the Australian Transport Safety Bureau in late June revealed an unexplained power outage early in the flight that may have been caused by tampering from the flight deck. In late June, the Malaysian government called pilot Zaharie Shah a 'prime suspect', after investigators discovered that he had used his personal flight simulator to prac-

\section{All at Sea}

China's relations with the Philippines and Vietnam have also deteriorated badly during the last twelve months over other maritime disputes, these related to the South China Sea (which the Philippines calls the West Philippine Sea). Manila incurred Beijing's wrath in March 2014 when it proceeded, in the face of strong Chinese opposition including threatened economic sanctions, to challenge China's territorial claims in the South China Sea through a United Nations tribunal. Beijing flatly refused to take part in this arbitration process. Chinese paramilitary vessels continued to harass Filipino fishermen in the disputed areas and, in March 2014, blockaded Filipino military forces stationed at the disputed Second Thomas shoal.

Tensions similarly intensified between Beijing and Hanoi in May 2014 when the state-owned China National Offshore Oil Corporation deployed 
tise journeys over the Indian Ocean. But there is no other evidence, no clear motive, and the case remains far from solved.

On 14 July, sixteen family members of victims went to the Malaysia Airlines' office in Shunyi, Beijing to demand to see official video footage of passengers boarding the flight, which the airline had

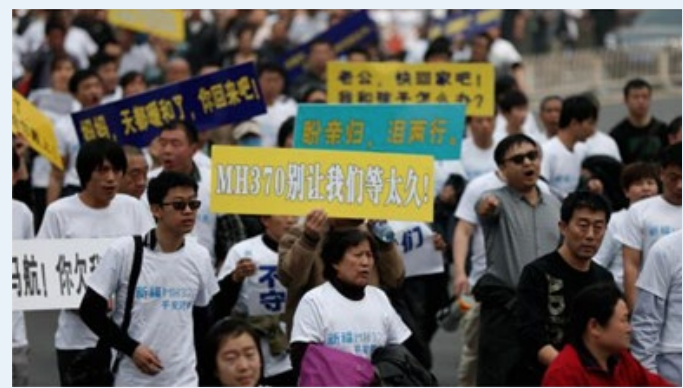

On 25 March 2014, family members of passengers on board flight MH370 marched on the Malaysian Embassy in Beijing demanding answers from the authorities

Source: Zhang Lintao

previously refused to release. The South China Morning Post reported that police arrived and detained all of them, and that two other female relatives of passengers alleged they were beaten by police officers 'after asking for the release of two other relatives - a father and daughter - who had been detained on a separate occasion'. The grieving families' demand is simple - in theory, at least: if the passengers are alive, they want to see them; if they are dead, they want to see the bodies.

a deep sea oil rig in the vicinity of the disputed Paracel Islands 西沙群岛, with a supporting force of at least eighty ships including military vessels. Both the Chinese and Vietnamese sides claimed that the other's ships had been ramming their own. Large-scale anti-China protests erupted in Vietnam targeting Chinese-owned businesses, causing a number of fatalities and serious injuries to Chinese nationals, and necessitating the evacuation by Beijing of more than 3,000 of its citizens.

In October 2013, meanwhile, President Xi visited Malaysia on a trip that was hailed by the Chinese media outlet Xinhua as ushering in 'a new era in Sino-Malaysian ties'. In 2014, the two countries would celebrate forty years of formal diplomatic relations. However, the mysterious disappearance of Malaysian Airlines flight MH370 with more than 150 Chinese nationals on board has strained mutual good will. China's citizens were vocal in their anger at the lack of information coming from Kuala Lum- 
pur and its mishandling of the search. Their frustration was shared by the Chinese authorities, who themselves often had to rely on media reports in the absence of official communications.

A map of Beijing's South China Sea claims included in Chinese passports and depicting those claims as encompassing the Natuna waters provoked an equally hostile reaction from the Indonesian capital, Jakarta. In March 2014, Commodore Fahru Zaini, assistant deputy to the Indonesian chief security minister for defence strategic doctrine, noted that China's claim now incorporated the waters around the Natuna Islands, which are part of the Riau Islands province of Indonesia. This prompted Jakarta to beef up its military presence in the South China Sea in the weeks and months that followed.

\section{Threats and Opportunities}

Relations between China and Australia also took a tumble from the high point they enjoyed in April 2013 when the two countries established a formal 'strategic partnership'. In September of that year, the newly elected Coalition government under Tony Abbott issued a statement

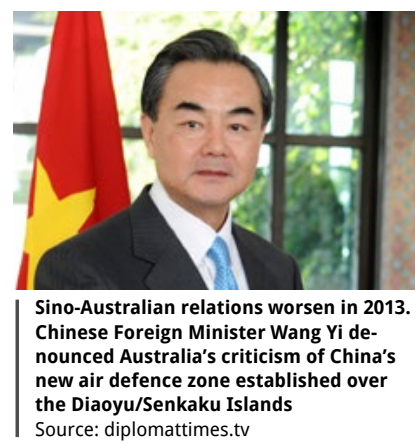
in conjunction with the US and Japan, as members of the Trilateral Strategic Dialogue, expressing their opposition to the use of force to change the status quo in the East China Sea. The Australian response to China's November 2013 ADIZ declaration was even more robust (and more sharply worded than that of even the US), with Canberra summoning the Chinese Ambassador to express its displeasure. When Australian Foreign Minister Julie Bishop visited Beijing the follow week, her frowning Chinese counterpart Wang Yi 王毅 publicly rebuked her and accused Australia of 'jeopardising mutual trust' and 'affect[ing] 




The potential pipelines that will be used to deliver Russian natural gas to China under the new deal signed by Gazprom and the China National Petroleum Corporation in May 2014

Source: RT/Gazprom

\section{Russia-China Pipeline, by Jeremy Goldkorn}

On 21 May 2014, on the sidelines of the Conference on Interaction and Confidence Building in Asia (CICA), Vladimir Putin and Xi Jinping looked on as Gazprom and the China National Petroleum Corporation signed an agreement for Russia to supply natural gas to China. The deal had been under negotiation for around a decade. Putin described the thirty-year, US $\$ 400$ billion deal as 'epochal'.

For Russia and China, who have long viewed each other as ideal energy partners, the mutual benefits appeared to be clear. Russia gained a new customer for its gas at a time when its relationship with the United States and Europe had become increasingly tense in the wake of Russia's annexation of Crimea. China, meanwhile, is highly motivated to find sources of cleaner energy and the government had already pledged to more than double the country's natural gas consumption by 2020 .

Gazprom CEO Alexei Miller told the media in Shanghai that the deal is Gazprom's biggest ever. Russian news agencies said the contract, calling for thirty-eight billion cubic metres of gas a year from 2018, specified a price of about US $\$ 350$ per thousand cubic metres, which is at the low end of what Gazprom currently charges export customers. 
the sound growth of bilateral relations'. An April visit by Abbott to China (along with Japan and South Korea) appeared to go some way toward arresting this downward slide. With 600 business people in tow, Abbott's visit even led to speculation that long-stalled Free Trade Agreement (FTA) negotiations between China and Australia could be finalised by the end of the year. However, trilateral statements issued by Australia, Japan and the US on the sidelines of the 2014 Shangri-La Dialogue - this time in relation to the South China Sea - continued to highlight ongoing tensions in the relationship between Beijing and Canberra. Officially, Australia still sees China's rise as an opportunity rather than a threat (notwithstanding polling which indicates the majority of Australians see it as both), and the Australian Prime Minister and senior government figures continued to reiterate the importance of the bilateral relationship.

While serious people in the Australian Department of Foreign Affairs and Trade (DFAT) and the Chinese Ministry of Foreign Affairs (MFA) worked hard to stabilise relations, a farcical but unwelcome episode was provided by businessman and MP Clive Palmer, of the eponymous Palmer United Party, and his Senate colleague Jacqui Lambie (see Forum 'PUP Barking', p.90). Angered by a falling out with his Chinese business partner, Palmer declared publicly that the Chinese were 'mongrels' who 'shot their own people'. Lambie opined that Australia should double the size of its military given the threat of a 'Chinese Communist invasion'. Prime Minister Abbott and Foreign Minister Bishop were quick to condemn these remarks, and this was noted by the Chinese MFA spokesperson, while expressing China's 'strong indignation and severe condemnation' of 'Palmer's insulting remarks'. The Global Times was less restrained, and following some fierce words concluded that China should reappraise its view of Australia, while noting it was a distant trade partner, a destination for Chinese tourists and a place where Chinese children could learn English 'with a bit of an accent'. The episode ended with Palmer writing not one but two letters of apology to the Chinese Ambassador. 


\section{A Deal in the Making?}

The only major country with which China's foreign relations do not appear to have gone backwards over the past year is Russia. Xi Jinping even chose Russia as the destination for his first foreign visit as president. During that visit he pledged

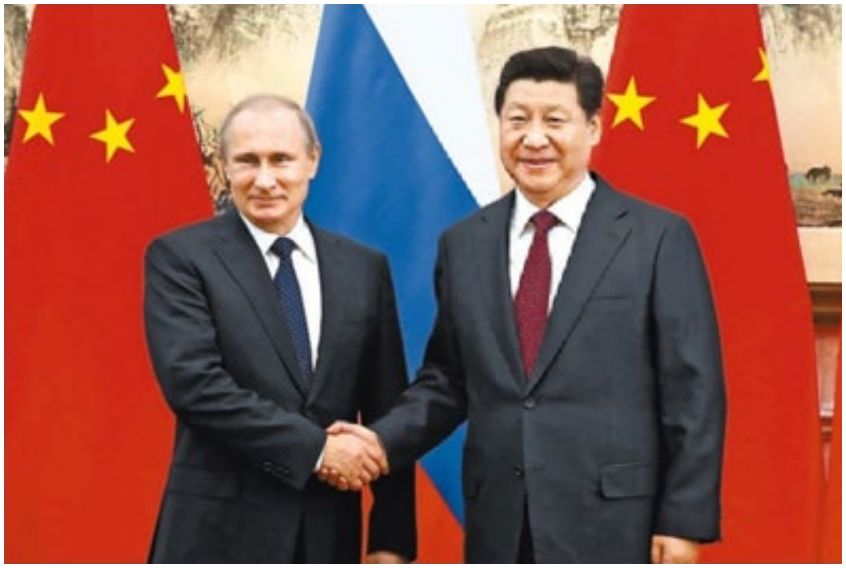

Relations between China and Russia strengthen: Presidents Putin and Xi, shown here at the 2014 APEC Summit held in Beijing. Their growing personal relationship emulates their countries' converging interests in trade investment and geopolitics Source: People's Daily Online

to President Vladimir Putin that he would 'closely coordinate [with him] on international regional affairs'. Then, in May 2014, Putin visited China, where he signed a deal that was a decade in the making for Russia to supply China with up to thirty-eight billion cubic metres of gas per year for thirty years starting in 2018.

Putin also attended the fourth summit of the CICA in Shanghai. CICA is a multilateral organisation whose most influential members are China and Russia and which is being chaired by China from 2014 to 2016. Xi used his keynote address to the 2014 CICA summit to propose a new 'Asian security concept': that Asia's problems should be solved by Asians themselves, not by external powers such as the United States. Putin's visit coincided with the aforementioned week-long military exercise between Chinese and Russian forces in the East China Sea.

Most international relations analysts outside China and Russia suggest that there is less than meets the eye to the warming of relations between Beijing and Moscow and warn against over-exaggeration. Even if one accepts that Sino-Russian relations have made some gains over the 
last year, the more pressing question is why Beijing's relations with so many of its other neighbours have gone backwards.

\section{Shared Destiny or Grand Strategy Disaster?}

Not surprisingly, there is no consensus. Brad Glosserman, executive director of the Pacific Forum, Center for Strategic and International Studies in Honolulu, for instance, characterises Beijing's current foreign policy approach as a 'grand strategy disaster' driven by a desire to secure the resource and energy needs required to fuel the country's continued economic growth. Rory Medcalf of Australia's Lowy Institute for International Policy, by contrast, sees it as a 'premature power play' by a Chinese leadership that has misjudged the extent of its still growing power and influence. The Australian defence analyst Hugh White, meanwhile, attributes Chinese foreign policy over the last year to a carefully calibrated effort to test suspect US alliances and strategic partnerships with the goal of undermining American power and influence in the Western Pacific.

If the reasoning behind Chinese foreign policy behaviour remains hotly contested, its potential consequences are clearer - and unsettling. The last twelve months have seen China forcefully assert its own interests vis-à-vis those of its neighbours and become more isolated as a consequence, particularly as its neighbours begin to co-ordinate their strategies in response. It is true that it is still early days for President Xi's leadership. As Zhai Kun 翟崑, formerly of the China Institute of Contemporary International Relations (CICIR) has observed in an essay analysing Xi's foreign policy approach: 'it is extremely difficult for the new leaders to make correct situational judgments and balance the timing, strength and rhythm of decision-making and implementation in a dynamic and smart way. Diplomacy is an art of experience and skills are gained through long-term practice. There is much to expect in this regard.' 
By the same token, Xi's actions in this and other areas are not those of a fledgling leader struggling to find his way. The heated exchanges witnessed between China and both the US and Japan at the June 2014 ShangriLa Dialogue could well be a sign of things to come. If over the coming year the gap between China's stated policies of good neighbourliness and the reality as perceived by others widens rather than narrows, the rhetoric of a 'community of shared destiny' may increasingly beg the questions: 'Whose community? Whose destiny?' 
This text is taken from Shared Destiny, edited by Geremie R Barmé, Linda Jaivin and Jeremy Goldkorn, published 2015 by ANU Press, The Australian National University, Canberra, Australia. 